\title{
Physical therapy for young men having vertebrogenic lumbosacral pain
}

\author{
Sasko I.A., Beziazychna O.V., Manucharian S.V. \\ Kharkiv State Academy of Physical Education, Ukraine
}

DOI: https://doi.org/10.34142/HSR.2019.05.04.07

\begin{abstract}
Objective: to develop and experimentally explain physical therapy methods for vertebrogenic lumbosacral pain.

Material and methods: 20 young men having vertebrogenic lumbosacral pain took part in the experiment at training motor mode, they were divided into two groups - experimental and control one, containing 10 people each. Men in experimental group had physical therapy according to original program, men from the control group - did it according to common recommendation of the Ministry of Health of Ukraine. Pedagogical and medico-biological studies have been carried out since October 2019 up to December 2019. Physical therapy courses in both experimental and control group lasted for two months. Clinical methods (medical history, visual examination), assessment according to Visual Analogue Scale of pain (VAS), lumbar spine mobility investigation, life quality evaluation according to Oswes try Disability Index questionnaire.

Results: The presented efficiency of physical therapy program for training motor mode using the exercises on Redcord Suspension System: dynamic exercises to improve spine mobility, static exercises to strengthen and improve core and lower extremity muscles endurance, exercises using slings to improve proprioception; therapeutic massage according to Yefimenko methods: massage of lumbosacral region of spine, glutes, favorable number of procedures - is 15-20 ones; instrumental physiotherapy methods: ultrasound $\left(1.2-1.4 \mathrm{~W}\right.$ - $\left.\mathrm{cm}^{2}\right)$, double-pole interference (25-27 mA), Trabert's current (7-8-12 mA).

Conclusions: In the course of study undertaken we have made a conclusion that physical therapy program developed and introduced at the premises of Kinezio Medical Center of Physical Rehabilitation and Sport Medicine in Kharkov for young men having vertebrogenic lumbosacral pain allowed advancing efficiency of medical rehabilitation, is accessible for all specialized rehabilitation facilities and appears worthy of practical application.

Key words: physical therapy; vertebrogenic lumbosacral pain; medical rehabilitation.
\end{abstract}

\section{Анотація}

Сасько І.А., Без'язична О.В., Манучарян С.В. Фізична терапія чоловіків молодого віку при вертеброгенному поперековокрижовому болю.

Мета роботи: розробити і експериментально обгрунтувати програму фізичної терапії при вертеброгенному поперековокрижовому болю.

Матеріал і методи. В експерименті брали участь 20 чоловіків молодого віку з вертеброгенним попереково-крижовим болем на тренувальному руховому режимі, які були розподілені на дві групи - експериментальну і контрольну, в кожній по 10 осіб. Чоловікам експериментальної групи заходи фізичної терапії проводилися за авторською програмою, чоловікам контрольної групи - за загальноприйнятими рекомендаціями МОЗ України. Педагогічні та медико-біологічні дослідження проводились 3 жовтня 2019 по грудень 2019 року. Курс фізичної терапії експериментальної та контрольної груп тривав протягом 2 місяців. При первинному і повторному дослідженні застосовувалися клінічні методи (збір анамнезу, зовнішній огляд), оцінка за візуальною аналоговою шкалою больових відчуттів за візуально-аналоговою шкалою болю, дослідження рухливості поперекового відділу хребта, оцінка якості життя за опитувальником Oswestry Disability Index.

Результати. Представлена ефективність програми фізичної терапії на тренувальному руховому режимі із застосуванням вправ на підвісній системі Redcord: динамічні вправи для покращення рухливості хребта, статичні вправи для зміцнення та покращення витривалості м'язів тулуба та нижніх кінцівок, вправи у слінгах для покращення пропріорецепції; лікувального масажу: масаж попереково-крижового відділу хребта, сідниць, оптимальна кількість процедур - 15-20; методи апаратної фізіотерапії: ультразвук (1,2-1,4 Вт-см²), двополюсна інтерференція (25-27 мАм), токи Траберта (7-8-12 мАм).

Висновки. В ході проведеного дослідження ми прийшли до висновку, що розроблена і впроваджена на базі медичного центру фізичної реабілітації та спортивної медицини «Кінезіо» м. Харкова програма фізичної терапії для чоловіків молодого віку з вертеброгенним попереково-крижовим болем дозволила підвищити ефективність відновного лікування, доступна для всіх спеціалізованих реабілітаційних центрів та заслуговує широкого впровадження в практику.

Ключові слова: фізична терапія; вертеброгенний попереково-крижовий біль; відновне лікування.

\begin{abstract}
Аннотация
Сасько И.А., Безъязычная О.В., Манучарян С.В. Физическая терапия мужчин молодого возраста при вертеброгенной поясничнокрестцовой боли.

Цель работы: разработать и экспериментально обосновать методику физической терапии при вертеброгенной поясничнокрестцовой боли.

Материал и методы. В эксперименте участвовали 20 мужчин молодого возраста с вертеброгенной пояснично-крестцовой болью на тренировочном двигательном режиме, которые были разделены на две группы - экспериментальную и контрольную, в каждой по 10 человек. Мужчинам экспериментальной группы физическая терапия проводились по авторской программе, мужчинам контрольной группы - по общепринятым рекомендациям Минздрава Украины. Педагогические и медикобиологические исследования проводились с октября 2019 по декабрь 2019 года. Курс физической терапии экспериментальной и контрольной групп продолжался в течение 2 месяцев. При первичном и повторном исследовании применялись клинические методы (сбор анамнеза, внешний осмотр), оценка по визуальной аналоговой шкале болевых ощущений, исследования подвижности поясничного отдела позвоночника, оценка качества жизни по опроснику Oswestry Disability Index.

Результаты. Представлена эффективность программа физической терапии на тренировочном двигательном режиме с применением упражнений на подвесной системе Redcord: динамические упражнения для улучшения подвижности позвоночника, статические упражнения для укрепления и улучшения выносливости мышц туловища и нижних конечностей, упражнения в слингах для улучшения проприорецепции; лечебного массажа: массаж пояснично-крестцового отдела позвоночника, ягодиц, оптимальное количество процедур - 15-20; методы аппаратной физиотерапии: ультразвук (1,2-1,4 Вт$\mathrm{CM}^{2}$ ), двухполюсная интерференция (25-27 мАм) тока Траберта (7-8-12 мАм).

Выводы. В ходе проведенного исследования мы пришли к выводу, что разработаная и внедренная на базе медицинского центра физической реабилитации и спортивной медицины «Кинезио» г. Харькова программа физической терапии для мужчин молодого возраста с вертеброгенной пояснично-крестцовой болью позволила повысить эффективность восстановительного лечения, доступна для всех специализированных реабилитационных центров и заслуживает широкого внедрения в практику. Ключевые слова: физическая терапия; вертеброгенная пояснично-крестцовая боль; восстановительное лечение
\end{abstract}




\section{Introduction}

At the present stage, vertebrogenic lumbosacral pain in most countries is more commonly used as "lower back pain" instead of the term. Lower back pain is a common problem among the working-age adult population, and its prevalence increases with age. The epidemiological study [1] combined the incidence of Canada, the United States of America (USA), Sweden, Belgium, Finland, Israel and the Netherlands. Primary incidence was 1.4 to $20.0 \%$, prevalence $0.024-7.0 \%$, respectively. Studies have shown that the chances of lower back pain in male patients were higher than in women (range 1.11-17.29).

Lumbar pain leads to a decrease in quality of life, a decrease in physical activity, the inability to lift heavy objects, sleep disorders, and the appearance of psychological disorders [2]. Among the etiologic facets, which cause the development of pain syndromes in the lower back, degenerative changes in bone and cartilage tissue osteochondrosis of the lumbosacral spine are most common. Pain syndrome is one of the major clinical neurological manifestations of spinal cord involvement. There are reflex and compression (root and cortex-vascular) syndromes. In the early stages of spinal osteochondrosis, as a rule, there are reflex syndromes, which manifest as muscular-tonic syndromes. The source of painful impulse are the fiberoptic ring muscles, muscles and capsules of the intervertebral joints. As a result of the painful impulsion, a muscle spasm occurs, which in turn exacerbates the pain, thus securing the pathological circle. The pain is triggered by a contraction of the muscle, and by the movement of the torso and extremities as a result of the extension of the affected muscle. The Redcord system uses sling therapy that utilizes the restoration of the stereotype of movement under the influence of high levels of neuromuscular stimulation. Thus, the regulation of muscle tone is normalized and neuromuscular re-training takes place, which helps to reduce pain and improve quality of life.

Questions of physical therapy of persons with vertebrogenic lumbosacral pain are covered in domestic and foreign works. In this regard, the development of physical therapy programs using the latest tools and techniques that are emerging every year is of particular interest. Therefore, it is relevant to justify the use of the Redcord Suspension System in physical therapy for this category of persons.
The purpose of the work was to scientifically substantiate, develop and evaluate the effectiveness of a program of physical therapy for young men with chronic ver-tebrogenic lumbosacral pain.

Tasks of work:

1. Based on the study of specialized literature, to analyze the basic approaches to physical therapy of persons with vertebrogenic lumbosacral pain.

2. To investigate the features of the clinicalfunctional condition of the spine and the quality of life of the injured before the application of physical therapy programs.

3. To develop a program of physical therapy for young men with chronic vertebrogenic lumbosacral pain on a training-motor mode, which includes kinesitherapy, therapeutic massage, physiotherapy.

4. To evaluate the effectiveness of our developed physical therapy program on the basis of studying the dynamics of the studied indicators of the examined contingent.

\section{Material and methods}

\section{Participants}

The study is based on the results of a survey of 20 men with chronic vertebrogenic lumbosacral pain, which were divided into 2 groups according to the random number method - control and experimental - 10 people each. The mean age in the experimental group was $39.20 \pm 0.87$ and in the control group it was $40.50 \pm 0.80$ years. According to the general characteristics, the presence of concomitant pathology, the experimental and control groups were homogeneous.

\section{Procedure}

The studies were conducted at the Kinesio Clinic in Kharkiv.

Under our observation, there were 20 men with chronic vertebrogenic lumbosacral pain, which were divided into 2 groups according to the method of case-by-case numbers - control and experimental - 10 people in each group. The study was conducted on the basis of the medical center of physical rehabilitation and sports medicine "Kinesio" in Kharkiv. In terms of number of persons, age, presence of concomitant pathology, the groups were one-kin.

Physical therapy measures were conducted according to the author's program to the men of the 
experimental group, to the control group men according to generally accepted recommendations of the Ministry of Health of Ukraine.

The developed program of physical therapy on exercise training involves the use of measures using exercises on the suspension system Redcord: dynamic exercises to improve spine mobility, static exercises to strengthen and improve endurance of the muscles of the trunk and lower extremities, exercise in slipping; of forging massage according to the method of Efimenko: Massage of the lumbar spine, buttocks, optimal number of procedures - 15-20; methods of hardware physiotherapy: ultrasound (1.2$1.4 \mathrm{~W}-\mathrm{cm} 2)$, two-scale interference (25-27 mAhm), Trabert currents (7-8-12 mAhm).

In the initial examination (at the beginning of the training motor mode), all men had complaints of periodic pain in the area of the buttocks and sacrum, which irradiates the back of the thigh and in the gluteal area, intensified in the morning after sleeping or after heavy physical work.

Palpation of the paravertebral points of the Valais in the area of spinous from-sprouts of the vertebrae $\mathrm{L} 1-\mathrm{S} 1$ revealed in almost all subjects pain in the lumbar spine, limitation of the mobility of the sacro-sacral spine.

In the initial study, the intensity of pain on the "Visual-analogue pain scale" men of both groups was assessed as moderate, on the visual-analogue pain scale $-5.30 \pm 0.26$ points in patients of the experimental group and $4.80 \pm 0,20$ points - control (table. 1).

Assessment of pain by patients on a visual-analogue scale of pain at the initial examination

\begin{tabular}{ccccc}
\hline \multirow{2}{*}{ Indicators } & EG & CG & & \\
& $\mathrm{n}=10$ & $\mathrm{n}=10$ & $\mathrm{t}$ & \\
\cline { 2 - 4 } & $\bar{x} \pm \mathrm{m}$ & $\bar{x} \pm \mathrm{m}$ & 1,52 & $>0,05$ \\
\hline Feelings, points & $5,30 \pm 0,26$ & $4,80 \pm 0,20$ & & \\
\hline
\end{tabular}

Notes:

EG - the experimental group

CG - the control group

In the initial examination, it was important to evaluate the functional and spinal condition. According to the functional study, the indexes of the amplitude of the spine movement in the lumbar section forward in the sagittal plane, right and left in the front plane were determined.

In males of the experimental group, the mean value of the forward spinal mobility was $70.00 \pm$ 0.94 , respectively; in the sagittal plane to the right and to the left $-11,00^{\circ} \pm 0,29$ and $13,20 \pm 0,46 \mathrm{~cm}$, respectively. In control group members, the mean forward spine mobility was $68.18 \pm 0.62$; in the sagittal plane to the right and to the left $-11.60^{\circ} \pm$ 0.26 and $12.00^{\circ} \pm 0.51$, respectively.

According to the data presented, the men of both groups showed a significant deterioration of the mobility (flexibility) of the spine in the lumbar department when bending and tilting to the right and left, no statistically significant differences were observed, but were statistically significantly reduced compared with the general. The results of the analysis of indicators of goniometry of the lumbosacral spine in the studied persons are presented in table 2 .

Table 2

Comparative indexes of goniometry of the lumbar spine in men of both groups at the initial examination

\begin{tabular}{|c|c|c|c|c|c|}
\hline \multirow{2}{*}{\multicolumn{2}{|c|}{$\begin{array}{l}\text { Indicators of available volume of } \\
\text { movements }\end{array}$}} & $\begin{array}{c}E G \\
n=10\end{array}$ & $\begin{array}{c}\text { CG } \\
\mathrm{n}=10\end{array}$ & \multirow[t]{2}{*}{$\mathrm{t}$} & \multirow[t]{2}{*}{$\mathrm{p}$} \\
\hline & & $\bar{x} \pm \mathrm{m}$ & $\bar{x} \pm \mathrm{m}$ & & \\
\hline \multirow{3}{*}{ 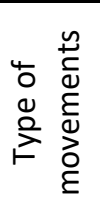 } & $\begin{array}{l}\text { Bending - forward tilt, angle of } \\
\text { deflection }\left({ }^{\circ}\right)\end{array}$ & $70,00 \pm 0,94$ & $68,16 \pm 0,62$ & 1,71 & $>0,05$ \\
\hline & $\begin{array}{l}\text { Tilt to the right, deviation } \\
\text { angle }\left({ }^{\circ}\right)\end{array}$ & $11,00 \pm 0,29$ & $11,60 \pm 0,26$ & 1,50 & $>0,05$ \\
\hline & Left tilt, deviation angle $\left({ }^{\circ}\right)$ & $13,20 \pm 0,46$ & $12,00 \pm 0,51$ & 1,72 & $>0,05$ \\
\hline
\end{tabular}

Notes: EG - the experimental group; CG - the control group 
In the initial survey, the quality of life score for the Oswestry Disability Index questionnaire in the experimental group was $30.5 \pm 2.03 \%$, and in the control group it was $28.00 \pm 6.32 \%$, which corresponds to "above average" statistically significant there were no differences in the studied indicators (Table 3 ).

Questionnaire Quality of Life comparative indicators Oswestry Disability Index on initial examination

\begin{tabular}{|c|c|c|c|c|}
\hline \multirow[t]{2}{*}{ Scale } & $\begin{array}{c}\text { EG } \\
n=10\end{array}$ & $\begin{array}{c}\mathrm{CG} \\
\mathrm{n}=10\end{array}$ & $\mathrm{t}$ & $\mathrm{p}$ \\
\hline & $\bar{x} \pm \mathrm{m}$ & $\bar{x} \pm \mathrm{m}$ & & \\
\hline Oswestry Disability Index, \% & $30,50 \pm 2,03$ & $28,00 \pm 2,00$ & 0,87 & $>0,05$ \\
\hline
\end{tabular}

Notes:

$\mathrm{EG}$ - the experimental group

$\mathrm{CG}$ - the control group

Thus, the analysis of the results of the study of the features of the clinical and functional condition of the spine and the quality of life of individuals with vertebrogenic cross-sacral pain, made it possible to outline the main set of tasks that need to be addressed in the process of developing a physical therapy program.

The rehabilitation intervention algorithm (duration of intervention 2 months) for men of both groups consisted of:

1. Survey:

- review;

- evaluation on a visual analogue scale of pain sensations;

- study of the mobility of the lumbar spine;

- Quality of life assessment using the Oswestry Disability Index.

2. Setting the goals of the intervention:

- long-term;

- short-term.

3. Planning of rehabilitation intervention (preparation of programs):

- kinetherapy;

- massage;

- physiotherapy.

4. Rehabilitation intervention.

5. Assessment of the intervention.

The physical therapy program was developed based on the detection of pathobiomechanical changes in the spine and the surrounding musculoskeletal system.

The developed program for the experimental group included the use of kinesitherapy by a modified method, therapeutic massage by the method of Efimenko and physiotherapy [3, 4, 5].

The basis of kinesitherapy was the exercises on the Redcord suspension system: dynamic exercises for improving spine mobility, static exercises for strengthening and improving endurance of the muscles of the torso and lower extremities, sling exercises for improving proprioception (Fig. 1).

Duration of the lesson is 40-60 minutes, №

12-16. Massage was carried out according to the method of Efimenko [3, 4]. During the massage procedure, it was taken into account that the spine is the only functional system. According to the anatomical structure, most of the paravertebral muscles unite 2-3 of its sections. Therefore, with vertebrogenic pain of any localization, you should massage the entire spine from the sacrum to the nape of the neck, paying attention to the affected areas.

The proposed massage method was conditionally divided into main and special parts. The main tasks of the procedure are:

- eliminate the external manifestations of vertebrogenic disorders of the lumbosacral spine: muscular hypertension in the paravertebral and remote areas of the affected vertebral-motor segment, muscular seals of metabolic origin, pain;

- normalize the trophism of the massaged tissues.

To do this, massage the muscles and their tendons along the back with the application of both basic and special, local massage techniques.

The task of the special part of the massage procedure is aimed at the local elimination of the primary manifestations of vertebrogenic lumbarsacral pain:

- to activate deep capillary circulation, to improve the tissue trophism of the affected vertebralmotor segments and to create conditions for their regeneration;

- normalize the mobility of the affected vertebral-motor segment.

There are special massage manipulations in the area of the affected arcuate processes and the adjacent edge of the intervertebral discs. 

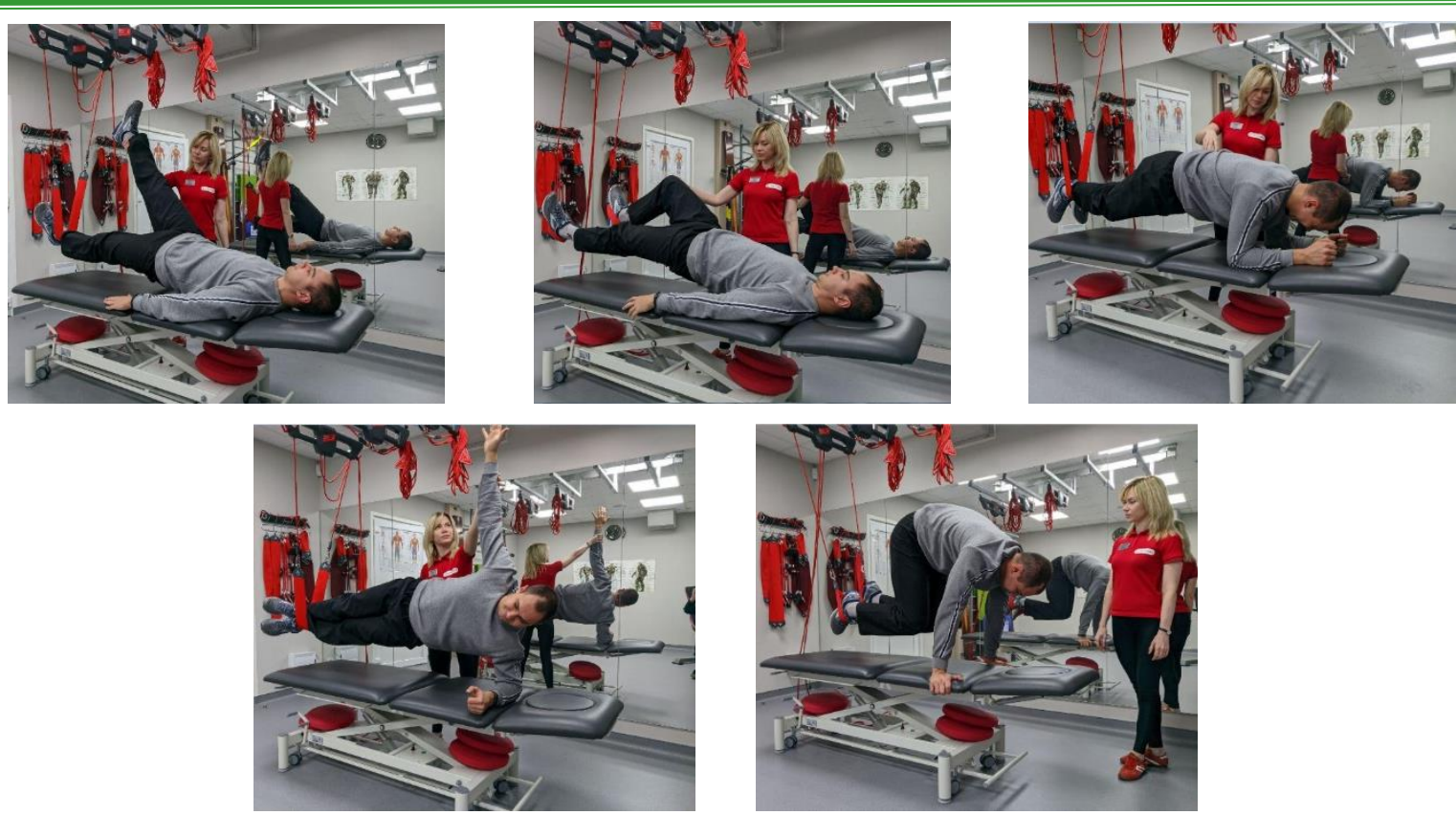

Fig. 1. Exercises on the Redcord suspension system

Starting position of the patient: lying on his stomach, hands along the torso, head to the side, under the ankle joints, place a massage roller. With an increased lumbar lordosis under the abdomen put a solid pillow.

The bulk of the massage is carried out according to the method described above with the only difference being that the condition of the massaged soft tissues in the lumbar region is the main focus. Finally, they carefully rub the sacrum, iliac sacrum and iliac crest.

In the special part, deep circular rubbing of the tips of the fingers in the area of the base of the spinous processes is carried out, that is, in the months as close as possible to the arcuate joints and the posterior surface of the intervertebral discs of the lumbar spine. To do this, first the fingers of both hands slowly, softly penetrate between the spinous processes and the paravertebral muscles and smoothly, without jerks, divert them away from the spine. It is very important that you do not allow these muscles to slip under your fingers in the opposite direction. Then, too, with no jerks, fingers are turned back to spinous processes and the deep layers of the massaged area are rubbed with screw motions. In this case, they start from L5 and end at 11 .

Finally, for greater effect, you should massage your buttocks. It is performed according to the usual procedure, excluding shock techniques. The duration of the procedure is 20-30 minutes, daily or every other day, No. 12-16. Physiotherapy included: ultrasound (1.2-1.4 W/sm ${ }^{2}$ ), bipolar interference (25$\left.27 \mathrm{~mA} / \mathrm{sm}^{2}\right)$, Trabert currents $\left(7-8-12 \mathrm{~mA} / \mathrm{sm}^{2}\right)$.

Physiotherapy procedures daily or every other day (as recommended by your doctor), No. 10-
12. The men of the control group were engaged in the generally accepted recommendations of the Ministry of Health of Ukraine. The basis of kinesitherapy were special exercises: stretching exercises with the use of fitballs, a gymnastic stick, formation of the correct posture, exercises for strengthening the muscles of the torso and lower extremities with loading, with counteraction, exercises for restoring spine mobility, exercises on Yevminov's preventer [5,6]. Men of the control group were engaged in kinesitherapy 5 times a week for 45-60 minutes under the guidance of a physical therapist and independently, but 2-3 times each day at home.

Therapeutic back massage according to the classical method (lumbar spine) [5;8]. The duration of the procedure is 20-30 minutes, daily or every other day, No. 12-16. Physiotherapy: ultrasound, muscle stimulation [5, 8, 9]. Physiotherapy procedures daily or every other day (as recommended by your doctor), No. 10-12. Analysis of the results, their comparison with the initial data (registrations at the beginning of training mode) and evaluation were performed at the end of training mode.

\section{Results}

On re-examination, the average values of pain intensity on the visual-analogue pain scale changed significantly in both groups and were significantly lower in the experimental group.

The severity of pain on the visual-analogue scale of pain decreased by 2.8 points - in the experimental group, whereas in the control - only 1.7 points (Table 4). 
Assessment of knee joint function on a visual-analogue scale of pain at repeated examination

\begin{tabular}{ccccc}
\hline \multirow{2}{*}{ Indicators } & EG & CG & & \\
& $\mathrm{n}=10$ & $\mathrm{n}=10$ & $\mathrm{p}$ \\
\cline { 2 - 4 } & $\bar{x} \pm \mathrm{m}$ & $\bar{x} \pm \mathrm{m}$ & & \\
\hline Feelings, points & $1,90 \pm 0,17$ & $2,70 \pm 0,15$ & 3,39 & $<0,05$ \\
\hline
\end{tabular}

Notes:

EG - the experimental group

CG - the control group

Dynamics of pain indices of men in both groups on the visa-analogue pain scale under the influence of physical therapy programs are presented in Table 5.

Table 5

Dynamics of pain indices on the visual-analogue scale of pain in men of the experimental and control groups under the influence of physical therapy programs

\begin{tabular}{|c|c|c|c|c|}
\hline \multirow[t]{2}{*}{ Indicators } & Primary examination & Re-examination & \multirow[t]{2}{*}{$\mathrm{t}$} & \multirow[t]{2}{*}{$\mathrm{p}$} \\
\hline & $\bar{x} \pm m$ & $\bar{x} \pm m$ & & \\
\hline \multicolumn{5}{|c|}{ Experimental group, $\mathrm{n}=10$} \\
\hline Feelings, points & $5,30 \pm 0,26$ & $1,90 \pm 0,17$ & 12,75 & $<0,05$ \\
\hline \multicolumn{5}{|c|}{ Control group, $n=10$} \\
\hline Feelings, points & $4,80 \pm 0,20$ & $2,70 \pm 0,15$ & 9,00 & $<0,05$ \\
\hline
\end{tabular}

\section{Notes:}

EG - the experimental group

CG - the control group

Thus, the use of a modified physical therapy program for vertebrogenic lumbar sacral pain in the experimental group of patients allowed to reduce the level of pain more compared to the control group of patients. Re-examination showed improvement in spine mobility in the lumbar region in both groups, but a more steady improvement was observed in the experimental group. In the experimental group, the average flexural amplitude increased by $18.09^{\circ}$, the slope amplitude to the right by $7.40^{\circ}$, the amplitude to the left to the left by $4.80^{\circ}$, and in the control group by $12.91^{\circ}, 4.40^{\circ}$, and $3.5^{\circ}$ (Table 6 ).

Table 6

Comparative indices of goniometry of the lumbar spine in men of both groups at repeated examination

\begin{tabular}{|c|c|c|c|c|c|}
\hline \multirow{2}{*}{\multicolumn{2}{|c|}{$\begin{array}{l}\text { Indicators of available volume of } \\
\text { movements }\end{array}$}} & \multirow{2}{*}{$\begin{array}{c}\begin{array}{c}\mathrm{EG} \\
\mathrm{n}=10\end{array} \\
\bar{x} \pm \mathrm{m}\end{array}$} & \multirow{2}{*}{$\begin{array}{c}\text { CG } \\
\mathrm{n}=10 \\
\bar{x} \pm \mathrm{m}\end{array}$} & \multirow[t]{2}{*}{$\mathrm{t}$} & \multirow[t]{2}{*}{$p$} \\
\hline & & & & & \\
\hline \multirow{3}{*}{ 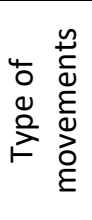 } & $\begin{array}{l}\text { Bending - forward tilt, angle of } \\
\text { deflection }\left({ }^{\circ}\right)\end{array}$ & $88,09 \pm 0,51$ & $81,09 \pm 0,90$ & 6,70 & $<0,05$ \\
\hline & $\begin{array}{l}\text { Tilt to the right, deviation angle } \\
\left({ }^{\circ}\right)\end{array}$ & $18,40 \pm 0,58$ & $16,00 \pm 0,51$ & 3,08 & $<0,05$ \\
\hline & Left tilt, deviation angle $\left({ }^{\circ}\right)$ & $18,00 \pm 0,51$ & $15,50 \pm 0,50$ & 3,47 & $<0,05$ \\
\hline
\end{tabular}

Notes:

EG - the experimental group

CG - the control group 
The results of the analysis of the dynamics of goniometry indices of the lumbar spine under the influence of physical therapy programs in patients in

Dynamics of goniometry indices of lumbar spine

control group and the experimental group are presented in Table 7.

Table 7

\begin{tabular}{|c|c|c|c|c|c|}
\hline \multirow{2}{*}{\multicolumn{2}{|c|}{$\begin{array}{l}\text { Indicators of available volume of } \\
\text { movements }\end{array}$}} & \multirow{2}{*}{$\begin{array}{c}\text { Primary examination } \\
\bar{x} \pm \mathrm{m}\end{array}$} & \multirow{2}{*}{$\begin{array}{c}\text { Re-examination } \\
\bar{x} \pm \mathrm{m}\end{array}$} & \multirow[t]{2}{*}{$\mathrm{t}$} & \multirow[t]{2}{*}{$\mathrm{p}$} \\
\hline & & & & & \\
\hline \multicolumn{6}{|c|}{ Experimental group, $\mathrm{n}=10$} \\
\hline \multirow{4}{*}{ 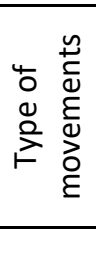 } & $\begin{array}{l}\text { Bending - forward tilt, angle } \\
\text { of deflection }\left({ }^{\circ}\right)\end{array}$ & $70,00 \pm 0,94$ & $88,09 \pm 0,51$ & 11,34 & $<0,05$ \\
\hline & $\begin{array}{l}\text { Tilt to the right, deviation } \\
\text { angle }\left({ }^{\circ}\right)\end{array}$ & $11,00 \pm 0,29$ & $18,40 \pm 0,58$ & 7,94 & $<0,05$ \\
\hline & Left tilt, deviation angle $\left({ }^{\circ}\right)$ & $13,20 \pm 0,46$ & $18,00 \pm 0,51$ & 7,94 & $<0,05$ \\
\hline & \multicolumn{5}{|c|}{ Control group, $n=10$} \\
\hline \multirow{3}{*}{ 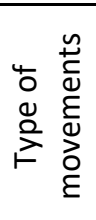 } & $\begin{array}{l}\text { Bending - forward tilt, angle } \\
\text { of deflection }\left({ }^{\circ}\right)\end{array}$ & $68,16 \pm 0,62$ & $81,09 \pm 0,90$ & 9,00 & $<0,05$ \\
\hline & $\begin{array}{l}\text { Tilt to the right, deviation } \\
\text { angle }\left({ }^{\circ}\right)\end{array}$ & $11,60 \pm 0,26$ & $16,00 \pm 0,51$ & 3,15 & $<0,05$ \\
\hline & Left tilt, deviation angle $\left({ }^{\circ}\right)$ & $12,00 \pm 0,51$ & $15,50 \pm 0,50$ & & \\
\hline
\end{tabular}

\section{Notes:}

EG - the experimental group

KG - the control group

When re-examined, the quality of life assessment of the Oswestry Disability Index questionnaire showed a statistically significant improvement in men in the Experimental and Control groups compared to the primary study. The mean in the experimental group was $10.00 \pm 1.29 \%$, and in the control group $16.00 \pm 1.00 \%$.

It should be noted that $30 \%$ of the experimental group experienced "excellent performance" (Table 8).

The dynamics of indicators for the Oswestry Disability Index questionnaire before and after physical therapy are presented in Table 9.
Therefore, the use of a modified physical therapy program with the use of kinesiotherapy based on exercises on the Redcord Suspension System (diphysical exercises to improve spine mobility, static exercises to strengthen and improve endurance of the muscles of the torso and lower extremities, exercises in slinging for slinging therapeutic massage by Yefimenko method in combination with physiotherapy has a more effective influence on the clinical and functional condition of the spine and quality of life.

Table 8

Questionnaire Quality of Life comparative indicators Oswestry Disability Index on re-examination

\begin{tabular}{|c|c|c|c|c|}
\hline \multirow[t]{2}{*}{ Scale } & $\begin{array}{c}\mathrm{EG} \\
\mathrm{n}=10\end{array}$ & $\begin{array}{c}\text { CG } \\
n=10\end{array}$ & $\mathrm{t}$ & $\mathrm{p}$ \\
\hline & $\bar{x} \pm \mathrm{m}$ & $\bar{x} \pm \mathrm{m}$ & & \\
\hline Oswestry Disability Index, \% & $10,00 \pm 1,29$ & $16,00 \pm 1,00$ & 3,67 & $<0,05$ \\
\hline
\end{tabular}

Notes:

$\mathrm{EG}$ - the experimental group

$\mathrm{KG}$ - the control group 
The dynamics of quality of life indicators according to the Oswestry Dis-ability Index questionnaire in men of the experimental and control groups under the influence of physical therapy programs

\begin{tabular}{|c|c|c|c|c|}
\hline \multirow[t]{2}{*}{ Scale } & Primary examination & Re-examination & \multirow[t]{2}{*}{$\mathrm{t}$} & \multirow[t]{2}{*}{$p$} \\
\hline & $\bar{x} \pm \mathrm{m}$ & $\bar{x} \pm \mathrm{m}$ & & \\
\hline \multicolumn{5}{|c|}{ Experimental group, $\mathrm{n}=10$} \\
\hline $\begin{array}{c}\text { Oswestry Disability } \\
\text { Index, \% }\end{array}$ & $30,50 \pm 2,03$ & $10,00 \pm 1,29$ & 9,46 & $<0,05$ \\
\hline \multicolumn{5}{|c|}{ Control group, $n=10$} \\
\hline $\begin{array}{c}\text { Oswestry Disability } \\
\text { Index, \% }\end{array}$ & $28,00 \pm 2,00$ & $16,00 \pm 1,00$ & 5,81 & $<0,05$ \\
\hline
\end{tabular}

\section{Discussion}

Currently, the problem of restoring the clinical and functional condition of the spine in individuals with vertebrogenic pain syndromes is becoming more acute due to the high prevalence and rigidity of this pathology. According to official statistics, degenerative-dystrophic lesions of the spine are the most common in the structure of the musculoskeletal disease in the world's population. In addition, in recent years, there is a tendency to increase the incidence of spine, which is primarily due to the lack of adequate physical activity, poor diet and sedentary lifestyle in the era of total computerization and, as a consequence, a decrease in tone $\mathrm{m}$ ' trunk ulcers holding the spine. Diagnosis and treatment of this severe form of spine damage are devoted to many scientific works not only of clinical, neurological and radiological orientation, but also in the field of physical therapy $[10,11]$.

Contemporary domestic and foreign scientific literature provides a description of numerous physical rehabilitation programs, which include kinesitherapy, massage, postisometric relaxation, physiotherapy, hydroquinisoterapia, traction treatments, which significantly restore the functional state of trainees and traumas. - syndromes and improve their quality of life $[12,13,14,15]$.

The main goal in treatment is to eliminate the pain symptom, since its presence affects the outcome of the restorative treatment. The therapy is used for the disease period: acute, subacute, and clinical (complete or incomplete) recovery $[2,16]$.

Kinesiotherapy in Ukraine is usually prescribed by the authors $[17,18]$. In chronic vertebrogenic pain syndrome, massage improves lymph and blood circulation in the muscles and at the site of destructive degenerative changes in the spine, has analgesic and resorptive effect, normalizes muscle tone, increases muscle strength. Apply massage to the subacute stage of the disease.
Massage is usually prescribed in Ukraine by methods $[5,3,4]$.

Physical methods are used in the complex therapy of muscular syndromes of degenerativedystrophic diseases of the spine. You-use of physical factors for therapeutic purposes is carried out taking into account the pathogenetic mechanisms of the syndromes.

The issues of physical therapy of persons with vertebrogenic pain syndromes are covered in a large number of domestic and foreign works.

Of particular interest is the development of physical therapy programs using the latest tools and techniques that are emerging every year. Therefore, it is relevant to justify the use of the Redcord Suspension System in physical therapy for this category of persons.

Using the Neursc technique, Redcord sling system allows you to: reduce or stop pain, restore full volume of joint movements, optimize neuromuscular control and coordination, and create motor patterns [19].

The main mechanism of this technique is the restoration of the functional-motor patterns by using high-level neuromuscular stimulation, the so-called feedback effect. The main element of the technique is exercises in closed kinematic circuits, which allow to reduce the damage of passive stabilizing elements, and also - to activate a large number of motor units of muscles, which has a tonic effect on the body [19, 20, 21].

Comparing the quality of life of men in groups, we came to the conclusion that when repeated in the experimental group after applying physical therapy measures under our advanced program, they were better, which has a positive effect on quality of life $(p<0.05)$.

Thus, the results of the study proved the effectiveness of the impact of physical therapy measures under our improved program on the quality 
of life of young people with vertebrogenic lumbarsacral pain on a treadmill.

\section{Conclusions}

1. The results of the analysis of literature data indicate that today the problem of restoring the functional condition of the spine of persons with vertebrogenic lumbosacral pain is very acute due to the high prevalence and rigidity of this pathology. In addition, in recent years there is a tendency to increase the incidence of spine, which is primarily due to the lack of adequate physical activity, poor nutrition and sedentary lifestyle in the era of total computerization and, as a consequence, a decrease in tone $\mathrm{m}$ ' trunk ulcers holding the spine.

2. Developing new and improving traditional physical therapy programs for individuals with vertebrogenic pain syndromes is an important task for those skilled in the art. In addition, the development of physical therapy programs using the latest tools and techniques that are emerging every year is of particular interest. Therefore, it is important to justify the use of the Redcord suspension system in physical therapy for this category of persons.

Prospects for further research are related to the development of a physical therapy program for chronic vertebrogenic lumbar sacral pain in trained individuals.

\section{Conflict of interest}

Authors state that there is no conflict of interest.

\section{References}

1. Fatoye F, Gebrye T, Odeyemi I. Real-world incidence and prevalence of low back pain using routinely collected data. Rheumatol Int. 2019 Apr; 39 (4): 619-626. doi: 10.1007/s00296-019-04273-0. (in English)

2. Romanenko VI, Romanenko IV, Romanenko YI. Clinical profiles of the patients having chronic sacrolumbar pain syndromes. Trauma. 2016; 17 (2): 78-85. (in Ukrainian)

3. Yefimenko PB. Differentiated approach to massage for patients having lumbosacral spine osteochondrosis. Slobozhansky Scientific and Sport Gazette. 2013; 3: 115-116. (in Ukrainian)

4. Yefimenko PB. Technique and methods of classic massage. Kharkiv: Kharkiv State Academy of Physical Culture; 2013. 296. (in Ukrainian)

5. Yepifanov VA, Yepifanov AV. Rehabilitation in traumatology and orthopedics. Moscow: GEOTARMedia; 2015. 416. (in Russian)

6. Babov KD, Kosoverov EO, Zoiarniuk OS. Physical therapy for the patients having chronic non-specific law-back pain. Pain Medicine Journal. 2018; 3 (2/1): 26. (in Ukrainian)

7. Fishchenko VY, Lazarev IA, Roy IV. Kinesitherapy for lumbar osteochondrosis; Kiev: Medical Book; 2007. 96. (in Ukrainian)

8. Goncharov OG. Integrated physical therapy program for the sportsmen having lumbosacral osteochondrosis. V: Materials of VI International External Research and Practice Conference. Psychological, pedagogical and medical and biological aspects of physical education and sport; 2015 Apr. 20-24; Odesa; 2015, 346-351. (in Ukrainian)

9. Lazareva OB. Physical therapy for patients having veretebrogenic pathology. Theory and methods of physical education and sport. 2008; 2: 74-78. (in Ukrainian)
10. Oliveira $\mathrm{CB}$ et al. Clinical practice guidelines for the management of non-specific low back pain in primary care: an updated overview. European Spine Journal. 2018; 27 (11): 2791-2803. (in English)

11. Kormiltseva VV. Physical therapy for patients having vertebrogenic pathology in remission using fitness aids [thesis abstract]. Kyiv: National University of Physical Education and Sport; 2014. 24. (in Ukrainian)

12. Paolucci T, Attanasi C, Cecchini W, Marazzi A, Capobianco SV, Santilli V. Chronic low back pain and postural rehabilitation exercise: a literature review. J Pain Res. 2018; 12: 95-107. doi: 10.2147/JPR.S171729. (in English)

13. Stochkendahl MJ et al. National Clinical Guidelines for non-surgical treatment of patients with recent onset low back pain or lumbar radiculopathy. European Spine Journal. 2018; 27 (1): 60-75. doi: 10.1007/s00586-017-5099-2. (in English)

14. Fairbank JC, Mbaot JC, Davies JB. The Oswestry Low Back Pain Disability Questionnaire. Physiotherapy. 1980; 66: 271-274. (in English)

15. Will JS, Bury DC, Miller JA. Mechanical Low Back Pain. American Family Physician. 2018; 98 (7): 421428. (in English)

16. Afanasiev SM. Role of risk factors in osteochondrosis progressing and clinical syndromes formation. Scientific Journal of NPU named after $M$. P. Dragomanov. Series: Scientific and Pedagogical Problems of Physical Culture. 2017; 4 (85): 10-15. (in Ukrainian)

17. Goncharov OG. Integrated physical therapy program at training motor mode for wrestlers-sport veterans having lumbosacral osteochondrosis [thesis research]. Kyiv: National University of Physical Education and Sport; 2019. 214. (in Ukrainian) 
18. Belova AN, Shchepetova ON. Rehabilitation scales, tests and questionnaires: Guidelines for doctors. Moscow: Antidor; 2002. 440. (in Russian)

19. Redcord medical active sport. Staubo, Norway, 2013. 11. (in English)

20. Shepelenko T, Kozina Z, Cieślicka M, Prusik K, Muszkieta R, Sobko I, et al. Factorial structure of aerobics athletes' fitness. Pedagogics, psychology,

\section{Information about the authors}

\section{Sasko I. A.}

iness2907@gmail.com

orcid.org/ 0000-0002-9817-4468

Kharkiv State Academy of Physical Education

Klochkivska st., 99. Kharkiv, 61058, Ukraine

Beziazychna O. V.

obezyazychnaya@gmail.com

orcid.org/ 0000-0001-9987-6405

Kharkiv State Academy of Physical Education

Klochkivska st., 99. Kharkiv, 61058, Ukraine

\section{Manucharian S. V.}

mybox3001@ukr.net

orcid.org/0000-0001-7256-3273

Kharkiv State Academy of Physical Education

Klochkivska st., 99. Kharkiv, 61058, Ukraine

Received: 04.11.2019 medical-biological problems of physical training and sports. 2017;21(6):345-52.

21. Bannikova RO, Kormiltsev VV, Brushko VV, Balazh MS. Factors determining the focus of physical therapy process for the men having lumbar osteochondrosis in remission. Slobozhansky Scientific and Sport Gazette. 2019; 1 (69): 43-47. doi:10.15391/snsv.2019-1.007. (in Ukrainian)

\section{Інформація про авторів}

\section{Сасько I.A.}

iness2907@gmail.com orcid.org/ 0000-0002-9817-4468

Харківська державна академія фізичної культури вул. Клочківська, 99. Харків, 61058, Україна

Без'язична О.В.

obezyazychnaya@gmail.com orcid.org/ 0000-0001-9987-6405

Харківська державна академія фізичної культури вул. Клочківська, 99. Харків, 61058,Україна

\section{Манучарян C.B.}

mybox3001@ukr.net

orcid.org/0000-0001-7256-3273

Харківська державна академія фізичної культури вул. Клочківська, 99. Харків, 61058, Україна

Принята в редакицию: 04.11.2019 